Kalashova Kh. Kh.

DOI: 10.25108/2304-1730-1749.iolr.2019.61.84-89

УДК 343.41

\title{
Issues of ensuring of human rights in the fight against terrorism
}

Abstract: Today terrorism in the world is one of the most serious threats in society. The degree of cruelty and degradation of this phenomenon is so great that it stimulates the devotion of every country facing the problem of terrorism. At the same time, practical efforts in this direction often lead to difficult dilemmas: how can one integrate national security with the commitment to respect human rights and freedoms?

International and national human rights organizations have repeatedly emphasized the cruelty of the methods used by many countries in the fight against terrorism. The so-called "destruction of terrorists" is a topic that has so far been so hot that it is difficult to imagine a targeted physical destruction of persons committed terrorist acts (often outside the state of the victim's state) are.

Keywords: international law; human rights and freedoms; powers of the state; fight against terrorism; armed conflict; serious threat.

"Destruction of terrorists" has designed to reduce the impact of the activities of all organizations and to overcome the resistance of terrorist organizations. In addition, they have played a role as an intimidating factor affecting the minds of potential terrorists. This method is actively used by the United States and Israel, and Russia has resorted to this method during the confrontation in Chechnya. Until now, the consensus of the "destruction of terrorists" in the minds of a civil society has shaped two completely polar positions.

The axiomatic character of the problem is moral choice between the protected and selfless benefits of an unethical character, such as ethics and the legal principle of life, social security, the authority of the state, that it is indispensable to solve it. At the same time, we begin to analyze the second function when preventing the "destruction of terrorists" function, which seems to be the strongest theoretical design, or when it loses its stability. In this regard, the features of "non-judicial proceedings" are derived from the act of revenge. On December 19, 2006, the application of nonjudicial proceedings to the United Nations General Assembly plenary session was considered to be a violation of the right to live decisively $[4, \mathrm{p} .6]$.

The United Nations Global Operational-Terrorism Strategy, adopted as a resolution on 8 September 2006, calls for the areas of law, especially human rights law, refugee rights, and international humanitarian law in combating terrorism, to fulfill their responsibilities. It should be noted that supporters of "isolated extermination" often try to combine terrorism with war. International law has two notions as "international armed conflict" and "international non-armed confrontation". In the context of each one, the legal basis of the state's activities have specific peculiarities. In the case of a conflict in the typology we mentioned, actions for the destruction of terrorists can be morally

\footnotetext{
'Kalashova Khayala Khaqani gizi - Senior Research Fellow of the Department for "The Legal Provision of State Security" of the Institute of Law and Human Rights of Azerbaijan National Academy of Sciences, Azerbaijan. E-mail: xayala_kalashova@yahoo.com
} 
justifiable because they are also directed against those who are enemies of the state using prohibited methods of war [1, p. 8].

However, the actions of the state should be carried out in accordance with the legal framework set out to prevent international armed conflicts. It can be stated that each State fighting terrorism can defend itself by using any means and methods legally based on the oppression of its competitors, excluding those who are directly exposed to international law. In particular, the Additional Protocol No. 1 to the Geneva Conventions of August 12, 1949, prohibits the use of weapons, marbles, substance and warfare methods that may result in unnecessary damages or unnecessary damages for the protection of victims of international armed conflicts.

Experience shows that, in most cases, the use of the method of "the destruction of terrorists" means and methods can not lead to unnecessary suffering, allowing it to be regarded as an acceptable act of terrorism. It should be noted that the state is exempt from the obligation to coordinate its actions with the relevant national legal bodies (such as the victim of a defensive or criminal offense) that define the conditions for the legitimacy of malicious acts. Nevertheless, to adopt such a method, it is necessary to conduct a terrorist activity on the part of a state that has become a public armed conflict. It is possible that the terrorists can be destroyed by the state on condition that the terrorist attack on their territory does not go beyond the borders of the armed conflict [5, p.5].

In accordance with the provisions of Annex II to the Geneva Conventions of 12 August 1949 relating to the protection of the victims of international armed conflicts, the conflict should be based on the armed forces of the armed forces against the armed forces and other armed groups subordinate to the responsible, conducts such a control allowing military action. According to Russian legislation, the illegal acts of subjects of non-international armed conflicts often form the basis of "joining an illegal armed group". It is often accompanied by terrorist activities during confrontation with the state. Persons referred to as "victims of conflict" should be careful about the content of Protocol No. 2, which prohibits the offense. There is no interpretation of this concept in this movement, but it is possible to recognize this status for representatives of the forces opposing the state from its text.

When they refuse to join the conflict, they voluntarily retain or retain power by the authorities. Consequently, the physical destruction of terrorists and the continued involvement in the conflict as members of illegal armed groups are theoretically acceptable in terms of international law. It should be noted that the extent and the destruction of its organizers among the terrorist acts committed at a time interval to the assessment of the legitimacy of such an action will not be affected. This position was reflected in the provisions of the 1950 European Convention on Human Rights and Fundamental Freedoms [2, p.1].

The United Nations High Commissioner for Human Rights in its report on "Human Rights, Combating Terrorism and Terrorism" states that the use of fatal force to be legitimate must always be consistent with the principle of necessity and should be exercised with self-defense or the protection of others' lives. At the same time, the principle of proportionality should always be respected and, if possible, the use of preventive measures that are not likely to be imprisoned or deprived of life. Measures to minimize and / or eliminate the manifestation of terrorism (hereinafter referred to as elimination of consequences) are anticipated in advance on the possible consequences of terrorist acts. "Targeted Killing" or "Destruction of Terrorists" is particularly relevant to the European Convention on Human Rights, which is incompatible with a number of international law. 
The Convention notes that if no right to life is provided, no one shall be deprived of his or her life and no one shall be subjected to torture except for human rights, the right to life and the sentence of judgment (exceptions shall be ensured, but the detainees shall not be allowed to escape, cannot be abolished. Success in combating terrorism can only be achieved by joint efforts of representatives of interested countries. These regular divisions dealing with the fight against terrorism will be ensured by holding bilateral and multilateral meetings of experts, special units.

Discussions and, in a practical sense, the position of authorities in relation to terrorists is moving in two directions. The first approach is used in Israeli practice to ensure that the terrorists were killed in all circumstances, even if these hostages were killed. The second approach involves the minimization of possible losses and the non-standard conditions imposed by the terrorists. At present, two international organizations, the UN and NATO, are in control of the conflicts in Afghanistan and Iraq in the Middle East after the conflicts and then after the conflicts. They faced various difficulties and consequences created by US policy in this region. Last time, the threat to international peace in Afghanistan has also legitimized the activities of the United States. Since 12 September 2001, the UN General Assembly and the Security Council have unanimously condemned terrorist attacks in the United States [6, p.2].

The ineffectiveness of preventing social incidents, the lack of legal, material and technical support, the imperfection of a normative legal framework, and legal nihilism affect the scale of terrorism. The disruption of the massacre of civilians, the destruction of material and religious values, the enmity between the social and national groups, and the dissolution of a particularly dangerous action accompanied by panic and fear prevents the normal life cycle of the dynamic life for years. His mercilessness and exceptional fears make people embarrassed.

Terrorism crimes in the Criminal Code of the Republic of Azerbaijan are part of the crimes against public security and public order. The goal is to undermine public safety, to create panic among the population, or to influence the decision-making by public authorities and international organizations, to cause significant harm to health. All of this creates the impression that the security of the population in certain regions cannot be guaranteed. Terrorism "affirms" people's memory, and its pains are not forgotten for a long time. Not being terrified when watching the world happening in recent years through television [7, p.1].

Since anti-terrorism is already an international phenomenon, the struggle against it implements the creation of an international organization. Terrorism refers to particularly severe crimes committed by violence. As a result of this act, innocent people are killed, ruins, explosions occur, fires make the surroundings paralyzed, and people become victims. Terrorism is a distinctive feature of the peaceful population, the authorities, the political system and the extreme fear of violence. The victims of this deed have nothing to do with terrorists, and they have nothing to do with it. Terrorists are always persistent in displaying cathodic results. The explosion of the World Trade Center in America in September 2001, the horrors the terrorist acts in the Ataturk Airport in Istanbul in June 2016 and the large-scale events in Nice, France. Today, terrorism is in the center of attention as a global problem and has extensive research. In the modern era only separate elements of terrorism are investigated, the criminal nature of the crime [8, p.2].

It is intended for the occurrence of explosions, fires, and other severe incidents, and the "conscious beings" of God are well aware of what they do and give him conscious speed. However, the actions of terrorists are more or less linked to the pressure on the authorities to compel them to make decisions. 
As the most dangerous and intricate event of the 21 st century, the scale of fear and terrorism of terrorism is expanding. The growth of its scope is inextricably linked with the inequality in determining the right to property, the conflict between the ethnic group and the national interest for power, to the antagonistic borders.

The ineffectiveness of preventing social incidents, the lack of legal, material and technical support, the imperfection of the normative legal framework - the legal nihilism affects the scale of terrorism. Danger of fear and anxiety by the civilian population, the destruction of material and religious values, hostility between social and national groups, and hostility, hindered the normalization of the dynamic life span throughout the years. His mercilessness and exceptional fears make people embarrassed. Terrorism, as it now exits the national framework, is an international character and combats it with the creation of an international organization.

This can be attributed to the particularly severe crimes committed by terrorism. As a result of this act, innocent people are killed, destructions, explosions occur, fires put the surroundings in a paralyzed state, and people become victims. Terrorism is a distinctive feature of the peaceful population, the authorities, the political system and the extreme fear of violence. Terrorism is a real threat and threat to the national security of each country, dominated by the daily routine of modern society.

\section{References}

1. Dopolnitel'nyi protocol II $k$ Zhenevskim konventsiyam ot 12.08.1949 g., kasayushiyisya zaschity zhertv mezhdunarodnykh vooruzhennykh konfliktovot 7 iyunya $1977 \mathrm{~g}$. [Additional Protocol No. 2 to the Geneva Conventions of 12 August 1949, which protects victims of international armed conflicts. Geneva, 8 June 1977]. Available at: https://www.icrc.org/en/ doc/ assets/files/other/icrc_002_0321.pdf (accessed 09.10.2019).

2. Zakon Rossiyiskoyi Federatsii "O politsii” ot 7 fevralya 2011 g. No. 3-FZ [the Law of Russian Federation "On Police” of 7 February 2011, No. 3-FZ]. Moscow, 2013, 14 p. Available at: http://www.garant.ru/ (accessed 09.10.2019).

3. Ugolovnyi Kodeks Azerbaijanskoyi Respubliki po sostoyaniyu na mayi 2018 g. [The Criminal Code of the Republic of Azerbaijan as of May, 2018] Available at: http://scfwca.gov.az/ en/page/mecelleler (accessed 15.10.2019).

4. Mezhdunarodnaya Konventsiya OON o bor'be s terrorizmom, $1997 \mathrm{~g}$. [UN International Convention on Combating Terrorism, 1997]. Available at: https://www.un.org/ru/documents/ decl_conv/conventions/bombing.shtml (accessed 11.10.2019).

5. URL: https://cyberleninka.ru/article/n/tochechnaya-likvidatsiya-kak-metod-protivodeystviyaterrorizmu-etiko-pravovaya-otsenka (accessed 11.10.2019).

6. URL: http://olaylar.az/news/dunya/185173(accessed 11.10.2019).

7. URL: http://www.e-qanun.az/framework/151141 (accessed 15.10.2019).

8. URL: http://www.alefmagazine.com/pub1436.html (accessed 11.10.2019). 


\section{Калашова X.X.•}

DOI: 10.25108/2304-1730-1749.iolr.2019.61.84-89

УДК 343.41

\section{Вопросы обеспечения прав человека в борьбе с терроризмом}

Аннотация: Сегодня терроризм в мире является одной из самых серьезных угроз в обществе. Степень жестокости и аморальности этого явления настолько велика, что он поощряет приверженность каждой страны к проблеме терроризма. В то же время практические усилия в этой области часто приводят к сложным дилеммам: как эффективно сочетать национальную безопасность с обязательством уважать права и свободы человека?

Международные и национальные правозащитные организации неоднократно подчеркивали жестокость методов, используемых некоторыми странами в борьбе с терроризмом. Темой, которая до сих пор была предметом обсуждения, является так называемое «уничтожение террористов» с целью преднамеренного уничтожения лиц, совершивших террористические акты (часто за пределами страны, пострадавшей от их действий), с целью последующего уголовного преследования.

Аксиоматический характер проблемы - это моральный выбор между защищенными и бескорыстными благами неэтичного характера, такими как этика и правовой принцип жизни, социальное обеспечение, авторитет государства, что для его решения необходимо. Глобальная оперативно-террористическая стратегия Организации Объединенных Наций, принятая в качестве резолюции 8 сентября 2006 года, призывает к выполнению своих обязанностей в таких областях права, как права человека, права беженцев и международное гуманитарное право в борьбе с терроризмом. Следует отметить, что сторонники «изолированного истребления» часто пытаются сочетать терроризм с войной. Однако действия государства должны осуществляться в соответствии с правовыми рамками, предусмотренными для предотвращения международных вооруженных конфликтов.

В результате террористического акта гибнут ни в чем не повинные люди, происходят разрушения, взрывы, пожары приводят в парализованное состояние окрестности, и люди становятся жертвами. Терроризм - это отличительная черта мирного населения, власти, политической системы и крайнего страха перед насилием. Терроризм - это реальная угроза и угроза национальной безопасности каждой страны, в которой доминирует повседневная жизнь современного общества.

Ключевые слова: терроризм; международное право; права и свободы человека; полномочия государства; борьба с терроризмом; вооруженный конфликт; серьезная угроза.

\footnotetext{
‘Калашова Хаяля Хагани кызы - старший научный сотрудник, отдел «Правовое обеспечение государственной безопасности», Институт права и прав человека НАНА, Азербайджан. E-mail: xayala_kalashova@yahoo.com
} 


\section{Библиография}

1. Дополнительный протокол II к Женевским конвенциям от 12.08 .1949 г., касающийся защиты жертв международных вооруженных конфликтов от 7 июня 1977 г. М.: 2016, 24 с. [Электронный ресурс]. - Режим доступа: https://www.icrc.org/en/doc/assets/files/other/icrc_002 _0321.pdf. (дата обращения: 09.10.2019).

2. Закон Российской Федерации «О полиции» от 7 февраля 2011 г. № 3-ФЗ. М.: 2013, 14 c. [Электронный ресурc]. - Режим доступа: http://www.garant.ru/(дата обращения: 09.10.2019).

3. Уголовно-процессуальный кодекс Азербайджанской Республики по состоянию на май 2018 г. [Электронный ресурс]. - Режим доступа: http://scfwca.gov.az/ru/page/mecelleler (дата обращения: 15.10.2019).

4. Международная Конвенция ООН о борьбе с терроризмом 1997 г. [Электронный ресурс]. - Режим доступа: https://www.un.org/ru/documents/decl_conv/conventions/bombing. shtml (дата обращения: 11.10.2019).

5. URL: https: //cyberleninka.ru/article/n/tochechnaya-likvidatsiya-kak-metod-protivodeystviya -terrorizmu-etiko-pravovaya-otsenka (дата обращения: 15.10. 2019).

6. URL: http://olaylar.az/news/dunya/185173 (дата обращения: 11.10.2019)

7. URL: http://www.e-qanun.az/framework/15114 1 (дата обращения: 15.10. 2019).

8. URL: http://www.alefmagazine.com/pub1436.html (дата обращения: 11.10. 2019). 